Prepared in cooperation with the Bureau of Reclamation, Yakama Nation Fisheries, and Washington Department of Fish and Wildlife

\title{
Evaluation of Water Temperature Effects on Adult Sockeye Salmon (Oncorhynchus nerka) Behavior in the Yakima River, Washington, 2019
}

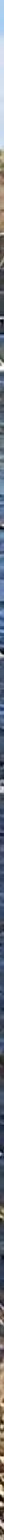


Cover: Tailrace of Wannawish Dam, Yakima River, Washington. Photograph by Tobias J. Kock, U.S. Geological Survey, June 25, 2019. 


\section{Evaluation of Water Temperature Effects on Adult Sockeye Salmon (Oncorhynchus nerka) Behavior in the Yakima River, Washington, 2019}

By Tobias J. Kock, Scott D. Evans, Amy C. Hansen, Brian K. Ekstrom, Richard Visser, Brian Saluskin, and Paul Hoffarth

Prepared in cooperation with the Bureau of Reclamation, Yakama Nation Fisheries, and Washington Department of Fish and Wildlife

Open-File Report 2020-1033

U.S. Department of the Interior

U.S. Geological Survey 


\section{U.S. Department of the Interior \\ DAVID BERNHARDT, Acting Secretary}

\section{U.S. Geological Survey James F. Reilly II, Director}

U.S. Geological Survey, Reston, Virginia: 2020

For more information on the USGS-the Federal source for science about the Earth, its natural and living resources, natural hazards, and the environment-visit https://www.usgs.gov/ or call 1-888-ASK-USGS (1-888-275-8747).

For an overview of USGS information products, including maps, imagery, and publications, visit https://store.usgs.gov/.

Any use of trade, firm, or product names is for descriptive purposes only and does not imply endorsement by the U.S. Government.

Although this information product, for the most part, is in the public domain, it also may contain copyrighted materials as noted in the text. Permission to reproduce copyrighted items must be secured from the copyright owner.

Suggested citation:

Kock, T.J., Evans., S.D., Hansen, A.C., Ekstrom, B.K., Visser, R., Saluskin, B., and Hoffarth, P., 2020, Evaluation of water temperature effects on adult sockeye salmon (Oncorhynchus nerka) behavior in the Yakima River, Washington, 2019: U.S. Geological Survey Open-File Report 2020-1033, 15 p., https://doi.org/10.3133/ofr20201033.

ISSN 2331-1258 (online) 


\section{Contents}

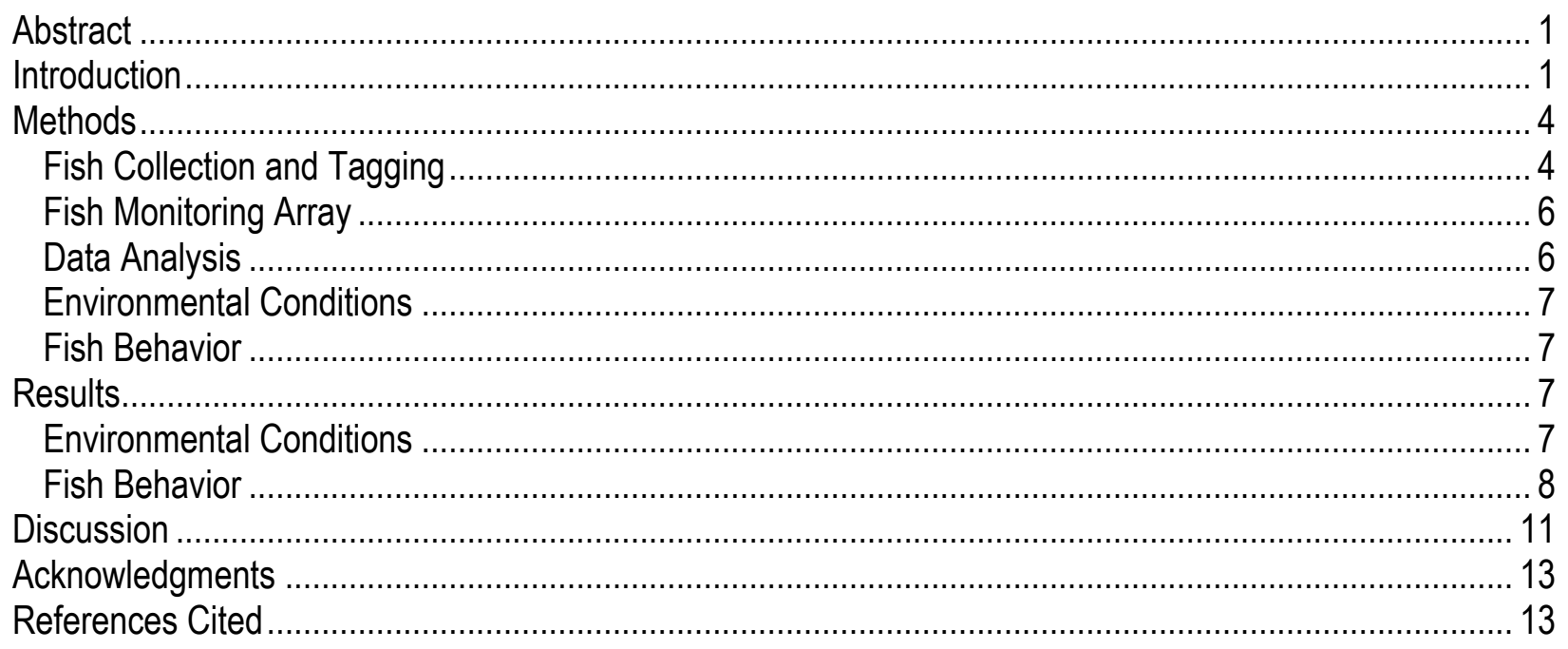

\section{Figures}

Figure 1. Graph showing average daily number of adult sockeye salmon passing McNary Dam, on the Columbia River, 2009-18.

Figure 2. Map image showing locations of fish release sites and fixed radio telemetry monitoring sites used to detect tagged fish in the Yakima and Columbia Rivers, Washington

Figure 3. Graph showing mean daily river flow and water temperature in the lower Yakima River, June 1-October 31, 2019.

Figure 4. Graph showing mean daily water temperature as measured at the Van Giesen Bridge (U.S. Geological Survey streamgage number 12511800) in Richland, June-July 2019, and number of tagged sockeye salmon that moved downstream and were detected on a fixed telemetry site near the mouth of the Yakima River, Washington, June 26-July 1, 2019.

Figure 5. Graph showing mean daily water temperature as measured at the Van Giesen Bridge (U.S. Geological Survey streamgage number 12511800) in Richland, August-October 2019, and number of tagged sockeye salmon that entered the Yakima River and were detected on a fixed telemetry site near the mouth, Washington, September 9-21, 2019.

Figure 6. Graph showing residence time of radio-tagged adult sockeye salmon at potential cool-water refugia sites on the lower Yakima River, Washington.

\section{Tables}

Table 1. Number of adult sockeye salmon returning annually to Roza Dam, Yakima River, Washington, 2013-19.

Table 2. Number of adult sockeye salmon collected and radio-tagged on the Lower Yakima River during 2019 . 


\section{Conversion Factors}

International System of Units to U.S. customary units

\begin{tabular}{lll}
\hline \multicolumn{1}{c}{ Multiply } & By & \multicolumn{1}{c}{ To obtain } \\
\hline centimeter $(\mathrm{cm})$ & Length & inch (in.) \\
millimeter $(\mathrm{mm})$ & 0.3937 & inch (in.) \\
meter $(\mathrm{m})$ & 0.03937 & foot (ft) \\
kilometer $(\mathrm{km})$ & 3.281 & mile (mi) \\
kilometer $(\mathrm{km})$ & 0.6214 & mile, nautical (nmi) \\
\hline & 0.5400 & ounce, fluid $(\mathrm{fl} . \mathrm{oz})$ \\
\hline liter $(\mathrm{L})$ & Volume & \\
\hline & 33.81402 & cubic meter per second $\left(\mathrm{m}^{3} / \mathrm{s}\right)$ \\
\hline cubic foot per second $\left(\mathrm{ft}^{3} / \mathrm{s}\right)$ & Flow rate & \\
\hline
\end{tabular}

Temperature in degrees Celsius $\left({ }^{\circ} \mathrm{C}\right)$ may be converted to degrees Fahrenheit $\left({ }^{\circ} \mathrm{F}\right)$ as follows:

$$
{ }^{\circ} \mathrm{F}=\left(1.8 \times{ }^{\circ} \mathrm{C}\right)+32 \text {. }
$$

\section{Abbreviations}

rkm river kilometer

USGS U.S. Geological Survey 


\title{
Evaluation of Water Temperature Effects on Adult Sockeye Salmon (Oncorhynchus nerka) Behavior in the Yakima River, Washington, 2019
}

By Tobias J. Kock1, Scott D. Evans ${ }^{1}$, Amy C. Hansen ${ }^{1}$, Brian K. Ekstrom¹, Richard Visser ${ }^{2}$, Brian Saluskin ${ }^{3}$ and Paul Hoffarth4

\begin{abstract}
A study was conducted in the lower Yakima River, Washington, during June-October 2019 to evaluate water temperature effects on adult sockeye salmon (Oncorhynchus nerka) behavior. A total of 60 sockeye salmon adults were tagged with radio transmitters and monitored during the study. Fourteen of the fish were collected and tagged at Prosser Dam in late June and the remainder were collected and tagged at the mouth of the Yakima River in late July. Water temperature exceeded 20 degrees Celsius $\left({ }^{\circ} \mathrm{C}\right)$, conditions shown to block upstream migration of adult sockeye salmon in other river systems, from June 9, 2019 to September 15, 2019. These elevated temperatures seemed to affect the behavior of tagged fish during this study. Fish that were collected and tagged at Prosser Dam left the Yakima River within days of release and tagged fish that were collected and released at the mouth of the Yakima River failed to enter and move upstream until mid-September when water temperature decreased to less than $(<) 20^{\circ} \mathrm{C}$. Monitoring sites were located adjacent to several known areas of cool-water inputs that may provide thermal refuge for fish in the lower Yakima River to determine if tagged fish spent time in these areas. Although several tagged fish moved repeatedly past these sites, most fish spent $<30$ minutes at any given site, indicating that fish were actively migrating past the sites rather than holding near cool-water inputs. A single tagged fish moved upstream to Roza Dam and was collected for upstream transport to Cle Elum Reservoir during our study. Additional research in subsequent years likely will be required to better understand how water temperature affects adult sockeye salmon in the lower Yakima River.
\end{abstract}

\section{Introduction}

The Yakima River, in Washington state, historically supported the largest run of sockeye salmon (Oncorhynchus nerka) in the Columbia River Basin, with an estimated 150,000-200,000 adults returning annually to spawn (Yakama Nation, 1990; Bureau of Reclamation, 2005).

\footnotetext{
${ }^{1}$ U.S. Geological Survey

${ }^{2}$ U.S. Bureau of Reclamation

${ }^{3}$ Yakama Nation Fisheries

${ }^{4}$ Washington Department of Fish and Wildlife
} 
Spawning historically occurred in four nursery lakes (Keechelus, Kachess, Cle Elum, and Bumping Lakes), but access to each of these lakes was blocked by dams constructed during 1904-10 (Yakama Nation, 1990). The construction of these dams prevented returning adult sockeye salmon from accessing the nursery lakes and the population eventually was extirpated. As a result, sockeye salmon were absent from the Yakima River for several decades until efforts were initiated in the 2000s to develop fish passage at dams in the upper Yakima River Basin and to reintroduce anadromous fish populations to areas that they historically occupied (Bureau of Reclamation, 2005; Matala and others, 2019).

In 2002, as part of a settlement agreement with the Yakama Nation, the Bureau of Reclamation (Reclamation) agreed to evaluate the feasibility of constructing fish passage structures at five reservoir dams in the Yakima Basin, eventually determining that this was feasible (Bureau of Reclamation, 2005, 2011). After the feasibility determination, Cle Elum Dam was chosen to be the first site where fish passage facilities were constructed. The Yakama Nation and Washington Department of Fish and Wildlife then began planning to reintroduce sockeye salmon into the Yakima Basin and in 2009, and the Yakama Nation began releasing adult sockeye salmon into Cle Elum Reservoir. The initial reintroduction effort consisted of outplanting 1,000 adult sockeye salmon into the reservoir where they could spawn along shorelines or move upstream into the Cle Elum River. Outplanted fish were collected for translocation at Priest Rapids Dam on the main-stem Columbia River and originally were destined for either the Wenatchee River or Okanogan River (Matala and others, 2019).

Monitoring indicated that outplanted adults were able to successfully spawn upstream from Cle Elum Dam and produce progeny that eventually migrated to the ocean (Brian Saluskin, Yakama Nation, oral commun. July 2017). Based on this success, annual outplanting efforts have continued since 2009 and in some years as many as 10,000 adult sockeye salmon collected at Priest Rapids Dam have been released into the reservoir. These releases now include fish from three origins: Wenatchee River and Okanogan River sockeye salmon from Priest Rapids Dam and Yakima River sockeye salmon that return and are collected at Roza Dam. The latter fish are progeny of sockeye salmon that spawned naturally, after outplanting, in the Cle Elum River. The number of adult sockeye salmon that returned to the Yakima River and were collected at Roza Dam has varied substantially from a low of 201 fish to a high of 3,742 fish since 2013 (table 1).

Table 1. Number of adult sockeye salmon returning annually to Roza Dam, Yakima River, Washington, 2013-19.

\begin{tabular}{cc}
\hline Year & Number of fish \\
\hline 2013 & 687 \\
2014 & 2,576 \\
2015 & 340 \\
2016 & 3,742 \\
2017 & 375 \\
2018 & 201 \\
2019 & 201 \\
\hline
\end{tabular}

Adult sockeye salmon pass McNary Dam (located 69 river kilometers [rkm] downstream from the Yakima River mouth) during June-August (fig. 1) each year and spawn in the upper Yakima River basin during September-November (Matala and others, 2019), but migratory conditions in the lower Yakima River during summer months may limit the number of fish that enter the river and move upstream for spawning. Water temperature in the lower Yakima River 
can exceed $24{ }^{\circ} \mathrm{C}$ when summer air temperature peaks (Appel and others, 2011), which prevents sockeye salmon from entering the river and migrating upstream. This phenomenon, referred to as a "thermal block", has been documented for sockeye salmon at several locations including the Fraser River in British Columbia (migration blocked at $18-22^{\circ} \mathrm{C}$; Macdonald and others, 2000) and the Okanogan River (migration blocked at $21-23^{\circ} \mathrm{C}$; Major and Mighell, 1967; Hatch and others, 1993) and Snake River in Washington (migration blocked at $22{ }^{\circ} \mathrm{C}$; Quinn and others, 1997). In addition to preventing adult sockeye salmon from entering the Yakima River during part of their normal migration period, elevated water temperature in the Yakima and Columbia Rivers has the potential to increase mortality of sockeye salmon adults, which has been documented in numerous studies throughout the Pacific Northwest (Rand and others, 2006; Keefer and others, 2008; Mathes and others 2010; Eliason and others, 2011; Martins and others, 2012; Jeffries and others, 2012).

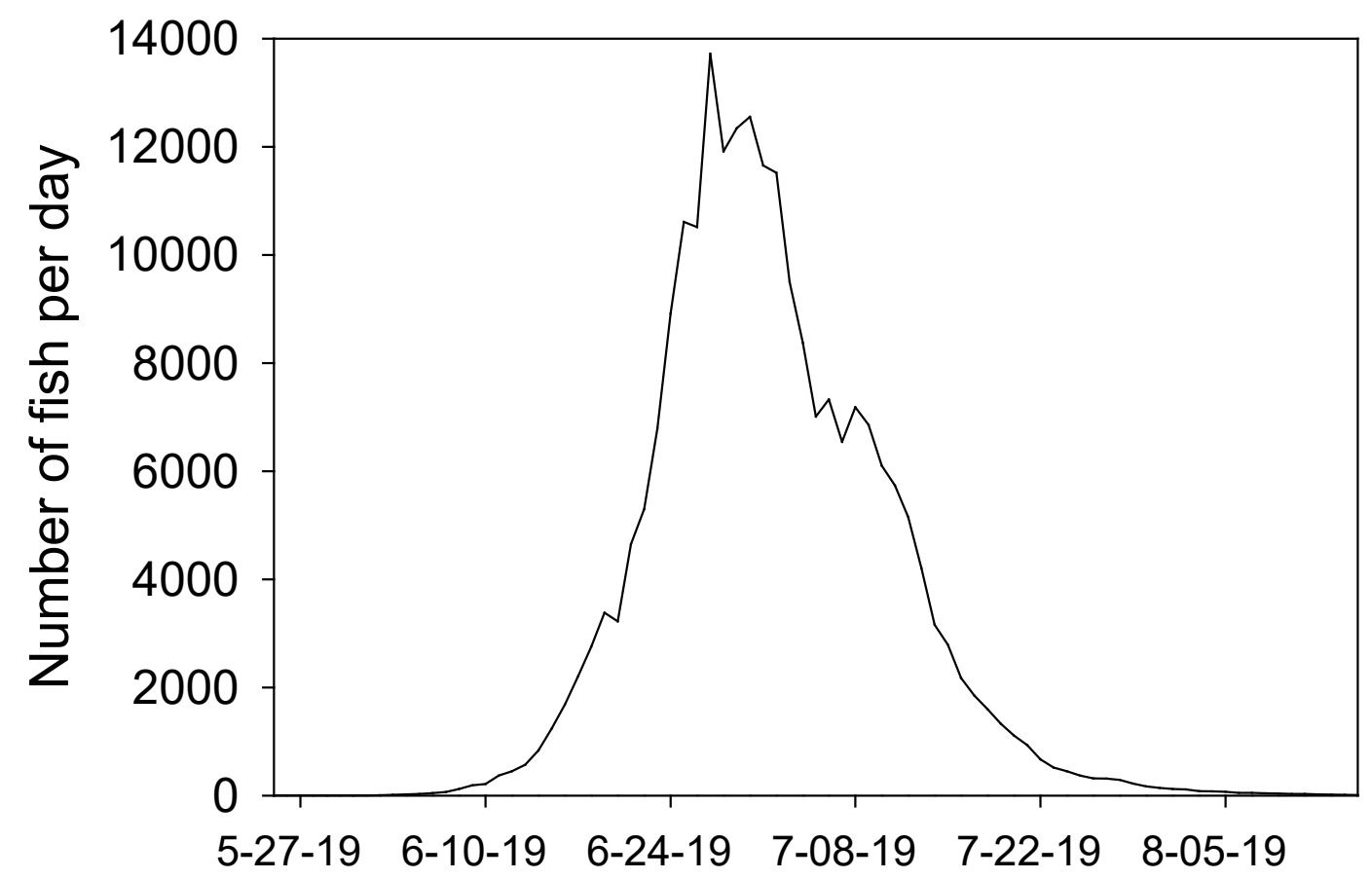

Figure 1. Graph showing average daily number of adult sockeye salmon passing McNary Dam, on the Columbia River, 2009-18.

Although elevated summer water temperature is a threat to adult sockeye salmon in the lower Yakima River, Appel and others (2011) collected temperature profile data in the reach between Prosser and Richland, Washington, during summer months in 2008 and 2009 and reported several areas of cool-water inputs near locations where groundwater discharge seeps and stream mouths enter the river. These areas of incoming cool water have the potential to provide thermal refuge and benefit adult sockeye salmon if they locate and use them as a source of thermal relief during extended warm periods. Sites such as these have been described in other systems as cool water (or cold water) refugia and are hypothesized to benefit fish species when present (Ebersole and others 2001; U.S. Environmental Protection Agency, 2012). As an example, Ebersole and other (2003) reported that increasing frequency and size of cold water patches were associated with increased abundances of rainbow trout (Oncorhynchus mykiss) and Chinook salmon (Oncorhynchus tshawytscha) in northeastern Oregon. 
Although much is known about thermal effects on sockeye salmon and thermal patterns in the lower Yakima River, research is lacking on how water temperature affects adult sockeye salmon behavior in the system. We conducted a study to evaluate this relationship during 2019. Adult sockeye salmon were collected in the lower Yakima River and at the mouth of the Yakima River, tagged with temperature-sensing radio transmitters, and released to monitor movement patterns and temperature exposure during their upstream migration. Our goal was to assess how water temperature affected the behavior of adult sockeye salmon in the lower Yakima River.

\section{Methods}

\section{Fish Collection and Tagging}

Adult sockeye salmon were collected and tagged at two locations during separate time periods of the study. Fourteen fish were collected and tagged at Prosser Dam from June 25 to June 28, 2019, and 46 fish were collected and tagged at the mouth of the Yakima River on July 23 and 24, 2019 (fig. 2; table 2).

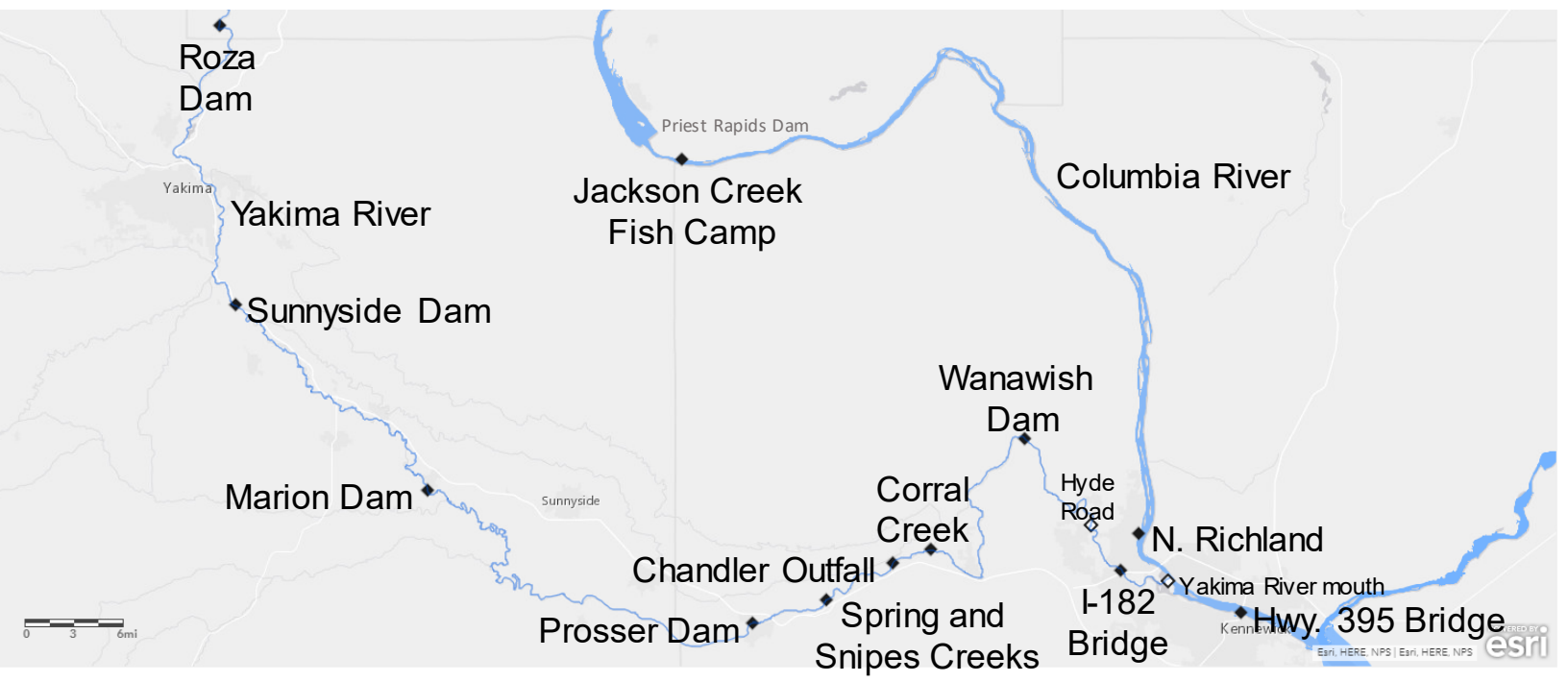

Figure 2. Map image showing locations of fish release sites (black open diamonds) and fixed radio telemetry monitoring sites (black closed diamonds) used to detect tagged fish in the Yakima and Columbia Rivers, Washington. Map image is the intellectual property of Esri and is used herein under license. Copyright ${ }^{\odot} 2020$ Esri and its licensors. All rights reserved. 
Table 2. Number of adult sockeye salmon collected and radio-tagged on the Lower Yakima River during 2019.

\begin{tabular}{lcccc}
\hline \multicolumn{1}{c}{ Collection location } & Tagging date & $\begin{array}{c}\text { Number } \\
\text { of fish } \\
\text { tagged }\end{array}$ & $\begin{array}{c}\text { Fork length } \\
\text { range } \\
\text { (centimeters) }\end{array}$ & $\begin{array}{c}\text { Temperature } \\
\text { sensor present } \\
\text { on transmitter }\end{array}$ \\
\hline Prosser Dam & June 25, 2019 & 4 & $38-58$ & Yes \\
Prosser Dam & June 26, 2019 & 5 & $39-58$ & Yes \\
Prosser Dam & June 27, 2019 & 3 & $34-54$ & Yes \\
Prosser Dam & June 28, 2019 & 2 & $55-56$ & Yes \\
Yakima River mouth & July 23, 2019 & 18 & $35-59$ & Yes \\
Yakima River mouth & July 23, 2019 & 11 & $33-45$ & No \\
Yakima River mouth & July 24, 2019 & 3 & $52-53$ & Yes \\
Yakima River mouth & July 24, 2019 & 14 & $33-49$ & No \\
\hline Total June 25-July 24 & & 35 & $34-59$ & Yes \\
& & 25 & $33-49$ & No \\
\hline
\end{tabular}

Fish collected at Prosser Dam were trapped in the southernmost fish ladder at the dam. To operate the fish trap, a weir was lowered into the fish ladder to prevent fish from moving upstream past the weir and water was diverted from the ladder through a steeppass that had an entrance located immediately downstream from the weir. To enter the trap, fish moved upstream through the steeppass and fell about $1 \mathrm{~m}$ into the wetted trap where they remained until tagging occurred. The trap was checked twice per day at about 6:00 a.m. and 6:00 p.m. Trapped fish were removed from the trap and tagged using the following process. Fish were hand netted from the trap and transferred to a 378-L holding tank that contained fresh river water. Each fish was measured to the nearest centimeter for fork length, sex was visually estimated, and a radio transmitter (Lotek Wireless; Model MCFT3-EM ${ }^{\circledR}$; Newmarket, Ontario, Canada) was gastrically implanted using methods described in Keefer and others (2004). The transmitters contained a sensor that recorded water temperature at 15 -minute intervals in addition to emitting a signal every 5 seconds. The internal record of water temperature was downloadable when transmitters were recovered at the end of the study. After tagging, fish were transferred to a fish hauling truck for downstream transport to the release site which was located at the Hyde Road boat ramp near rkm 13. Fish were released about 1 hour after each tagging session ended.

Angling was used to collect fish at the Yakima River mouth. The Washington Department of Fish and Wildlife organized a group of volunteer anglers to collect fish for tagging during a two-day period (July 23-24, 2019). On each day, a total of 16 anglers fished on five boats from about 5:00 a.m. until 11:00 a.m. The tagging crew was located on a sixth boat that remained close to the angling boats. The tagging crew monitored the angling boats continuously and pulled alongside individual boats to transfer fish into a 378 -L holding tank filled with fresh river water when fish were caught. Each fish was measured to the nearest centimeter for fork length, sex was visually estimated, and one of two radio transmitter models (Model MCFT3-EM ${ }^{\circledR}$, Lotek Wireless, Newmarket, Ontario, Canada; Model Pisces, Sigma Eight Inc., Newmarket, Ontario, Canada) was gastrically implanted. Model MCFT3-EM ${ }^{\circledR}$ transmitters included the temperature sensor described in the preceding paragraph. Model Pisces transmitters did not include a temperature sensor so an archival temperature logger (Thermochron iButton model DS1922L; Embedded Data Systems, Lawrenceburg, Kentucky) was attached to one end of the transmitter prior to tagging using methods described in Donaldson 
and others (2009). The archival temperature logger had an outside diameter of $17 \mathrm{~mm}$ that made gastric implantation difficult for fish with fork lengths $<45 \mathrm{~cm}$. In some cases, the temperature logger was removed from the transmitter at the time of tagging to facilitate gastric implantation of the transmitter (table 2).

\section{Fish Monitoring Array}

A total of 12 fixed monitoring sites were established to detect tagged fish moving within the study area. All monitoring sites contained radio telemetry equipment and were located downstream from Roza Dam on the Yakima River and downstream from Priest Rapids Dam on the Columbia River (fig. 2). Monitoring sites on the Yakima River were located in the tailrace of Roza Dam (rkm 205.8), at Sunnyside Dam (rkm 167.0), at the confluence of Marion Drain and the Yakima River just downstream from the Highway 223 bridge near Granger, Washington (rkm 132.6), at Prosser Dam (rkm 75.5), at the confluence of Spring and Snipes Creeks and the Yakima River (rkm 67.1), at Chandler Outfall (rkm 57.6), at the confluence of Corral Creek and the Yakima River (rkm 53.9), at Wanawish Dam (rkm 29.0), and at the I-182 Bridge (rkm 7.5). Monitoring sites on the Columbia River were located at Jackson Creek Fish Camp $4 \mathrm{~km}$ downstream from Priest Rapids Dam (rkm 635.0), $6 \mathrm{~km}$ upstream from the confluence of the Yakima and Columbia Rivers (rkm 546), and at the Highway 395 Bridge in Kennewick, Washington (rkm 532). Sites in the Yakima River were operated continuously from June 21 to November 6, 2019, except for the site at Chandler Power Plant, which operated from June 26 to November 6, 2019. Sites in the Columbia River were operated continuously from July 24 to October 28, 2019, except for the site located $6 \mathrm{~km}$ upstream from the Yakima River mouth, which was operated from July 1 to October 28, 2019.

Mobile tracking was conducted to collect additional information on the locations of tagged fish in the study area. A vehicle was used to slowly drive along the river, where feasible, while monitoring for the presence of tagged fish. In the lower Yakima River and Columbia River, we used a boat to mobile track. When a tagged fish was observed, the date, time, and Global Positioning System location of the detection location was recorded. Mobile tracking was conducted 1-4 times per month during the period in which tagged fish were monitored in the study area.

\section{Data Analysis}

Detection records from fixed monitoring sites were merged with tagging and release records to create a preliminary dataset. The preliminary dataset was then integrated with mobile tracking records to create a draft dataset that was proofed using an automated program to remove non-valid detection records. Records were determined to be non-valid if:

- They occurred prior to release,

- The signal strength was less than the 90th percentile of the signal strength of detections of tag identification codes that were not released during the study (noise),

- There were less than three consecutive detections at a given monitoring station (consecutive detections had to be 60 seconds or less apart), and

- It was impossible for the detection to occur geographically (for example, detections at separate locations with timestamps that would have exceeded the swimming capability of the fish). 
These criteria were used in the automated program to remove non-valid detection records from the dataset containing actual detections of study fish. The auto-proofed dataset was then manually reviewed to confirm that the autoproofing process was successful and to verify that the dataset could be considered final for analysis. This final dataset was used for all data queries and analyses presented in this report.

\section{Environmental Conditions}

We used data collected at existing flow gages in the Yakima River to describe water temperature and river flow patterns that occurred during the study. Daily water temperature data from the U.S. Geological Survey (USGS) streamgage located at the Van Giesen Bridge in Richland, Washington (about rkm 13.5; USGS streamgage number 12511800) were downloaded for the June 1, 2019-October 31, 2019 time period from the following site:

https://waterdata.usgs.gov/wa/nwis/uv/?site_no=12511800\&PARAmeter. Daily river flow data from the Reclamation streamgage located in the Prosser Dam tailrace (about rkm 75.6) were downloaded for the June 1, 2019-October 31, 2019 time period from the following site: https://www.usbr.gov/pnbin/yak/webarccsv.pl?station=YRPW\&year $=2019 \&$ month $=6 \&$ day $=1 \&$ year $=2019 \&$ month $=10 \&$ day $=31 \&$ pcode $=$ QD.

\section{Fish Behavior}

We examined the final dataset to describe the behavior of tagged fish that were released at Hyde Road and the Yakima River mouth. The percentage of tagged fish that moved upstream and arrived at Roza Dam was calculated by dividing the number of fish detected in the tailrace of Roza Dam by the number of tagged fish released. We queried detection records to determine if there was evidence that fish used cool-water refugia during their migration. To do this, we first calculated residence times of tagged fish at known areas of cool water inputs including Spring and Snipes Creeks, Chandler Outfall, Corral Creek, and I-182 Bridge sites. Residence times were determined by subtracting the time of first detection at each site from the time of last detection at that same site. If a fish made multiple trips past a site (a trip is defined as detection at a site after being detected at another site or detection at the same site after an absence of detections anywhere for greater than 1 hour) then the time spent at the site during the multiple trips was also included in the residence time (that is, it was possible for one fish to have multiple trips at a site). If fish used these sites as cool-water refugia, we would expect to see extended residence times at those sites.

\section{Results}

\section{Environmental Conditions}

Water temperature in the lower Yakima River exceeded $20{ }^{\circ} \mathrm{C}$ most days from early June to mid-September and exceeded $25^{\circ} \mathrm{C}$ during peak periods of this timeframe (fig. 3). River flows were about 2,300 $\mathrm{ft}^{3} / \mathrm{s}$ on June 1, 2019 and decreased to about $700 \mathrm{ft}^{3} / \mathrm{s}$ by mid-June where they remained until mid-August (fig. 3). On August 12, 2019, flows peaked at 2,400 $\mathrm{ft}^{3} / \mathrm{s}$ and then decreased to about $1,000 \mathrm{ft}^{3} / \mathrm{s}$ until early September when they began increasing again and

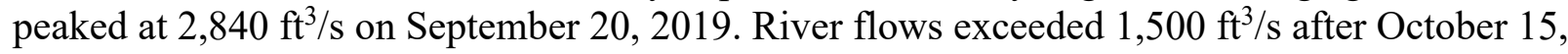
2019 (fig. 3). 


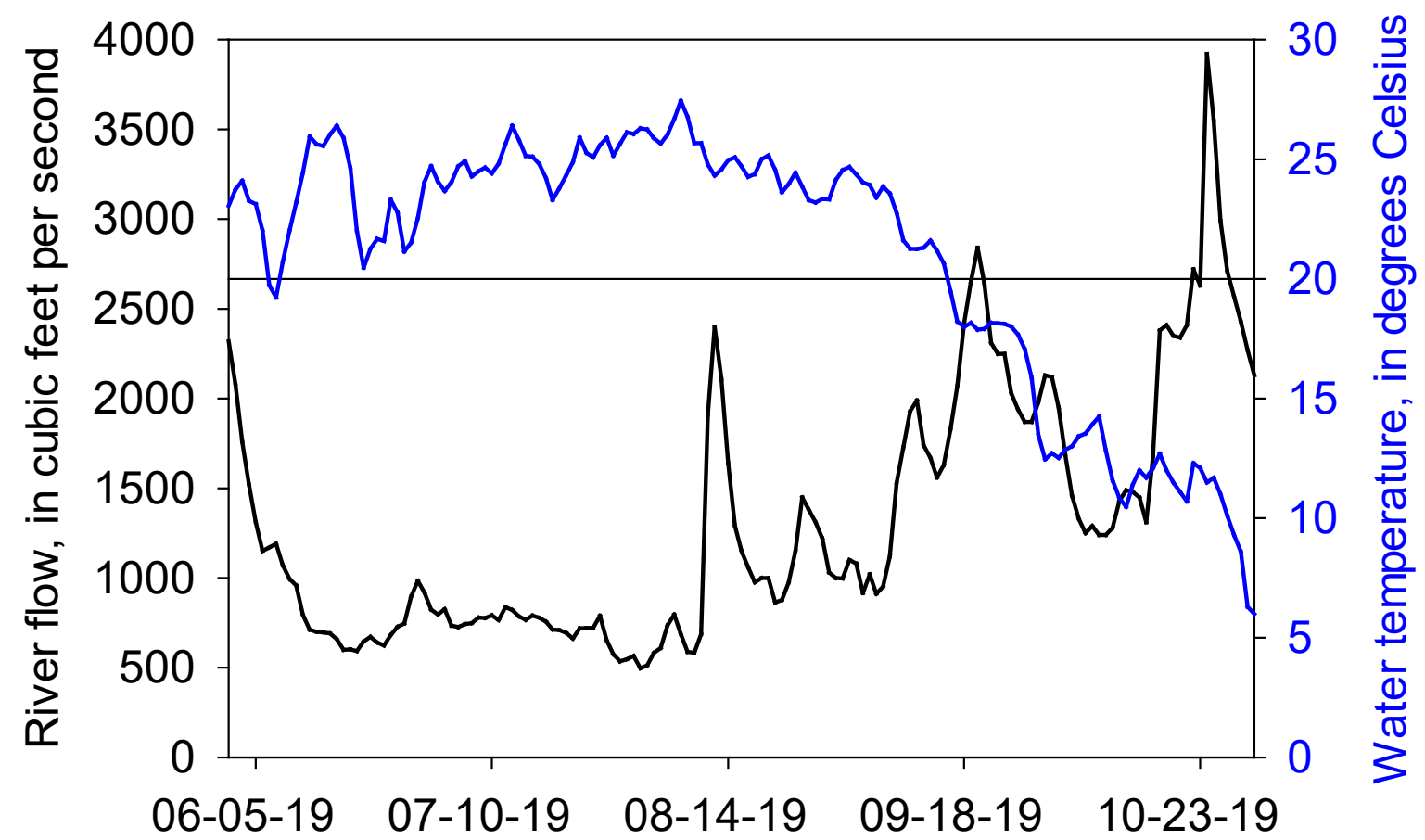

Figure 3. Graph showing mean daily river flow and water temperature in the lower Yakima River, June 1October 31, 2019. Horizontal reference line is located at 20 degrees Celsius for reference.

\section{Fish Behavior}

None of the 14 fish released at Hyde Road were detected upstream from Prosser Dam. Six of the 14 fish initially moved upstream after release, with the farthest upstream point of detection being Wanawish Dam for 4 fish, Corral Creek for 1 fish, and Spring and Snipes Creeks for 1 fish. All six fish eventually moved downstream, exited the Yakima River, and were last detected in the Columbia River. Seven of the remaining eight fish all moved downstream after release and were last detected in the Columbia River. All the tagged fish that moved downstream and left the Yakima River passed the I-182 Bridge site during a 6-day period from June 26 to July 1, 2019 (fig. 4). One of the 14 fish was never detected.

Of the 46 fish released at the mouth of the Yakima River, 25 (54 percent) were never detected, 9 fish (20 percent) never entered the Yakima River and were last detected in the Columbia River upstream from the release point, 4 fish (9 percent) never entered the Yakima River and were last detected in the Columbia River downstream from the release point, and 8 fish (17 percent) entered the Yakima River. The eight fish that entered the Yakima River did so from September 9, 2019 to September 21, 2019 as water temperatures were cooling in the lower Yakima River (fig. 5). The farthest upstream detection site for the eight fish that entered the Yakima River was Wanawish Dam for three fish, Prosser Dam for three fish, and Roza Dam for two fish. One of the two fish detected at Roza Dam was last detected at Sunnyside Dam and the other fish was collected at the Roza Adult Monitoring Facility. The radio transmitter was recovered from this fish but it did not have a temperature sensor because the fish was too small at the time of tagging. 
Of the combined 60 fish released at Hyde Road and the mouth of the Yakima River, 20 (33 percent) were detected swimming past potential cool-water refugia sites. Some fish were detected swimming past cool-water refugia sites multiple times, resulting in 19 fish making a total of 25 trips past I-182 Bridge, 7 fish making a total of 10 trips past Corral Creek, 6 fish making a total of 16 trips past Chandler Outfall, and 6 fish making a total of 17 trips past Spring and Snipes Creeks. Residence times at I-182 Bridge and Corral Creek were short (median times of 8.5 and 6.2 minutes, respectively), compared to longer residence times at Chandler Outfall and Spring and Snipes Creeks (median times of 3.6 and 2.3 hours, respectively; fig. 6). On average, fish tagged at Prosser Dam spent 28.8 minutes (in late June and early July) near these areas of cool-water refugia compared to 3.6 hours (in September and October) for fish tagged at the Yakima River mouth.

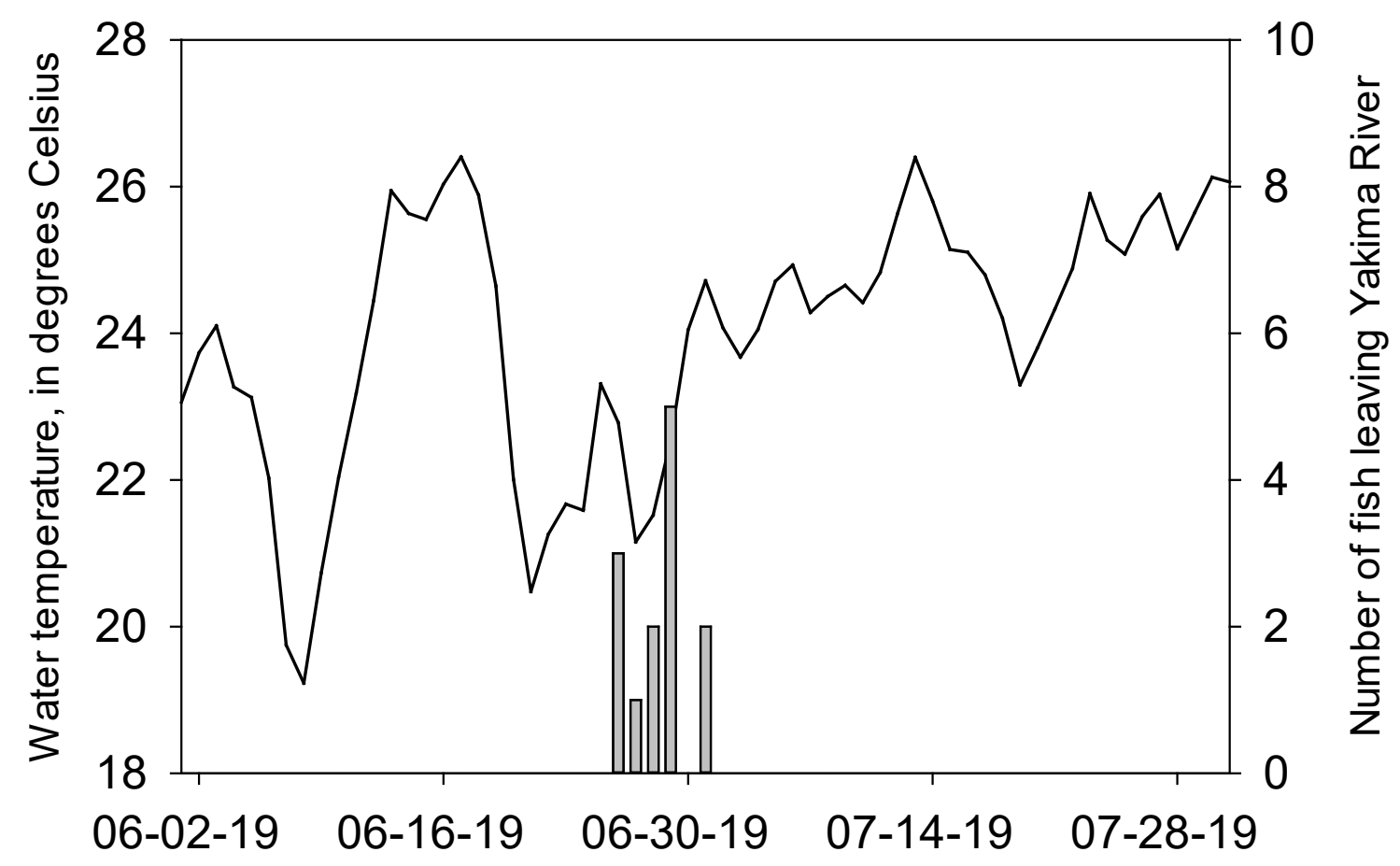

Figure 4. Graph showing mean daily water temperature (solid line) as measured at the Van Giesen Bridge (U.S. Geological Survey streamgage number 12511800) in Richland, June-July 2019, and number of tagged sockeye salmon (vertical bars) that moved downstream and were detected on a fixed telemetry site near the mouth of the Yakima River, Washington, June 26-July 1, 2019. 




Figure 5. Graph showing mean daily water temperature (solid line) as measured at the Van Giesen Bridge (U.S. Geological Survey streamgage number 12511800) in Richland, August-October 2019, and number of tagged sockeye salmon (vertical bars) that entered the Yakima River and were detected on a fixed telemetry site near the mouth, Washington, September 9-21, 2019. 


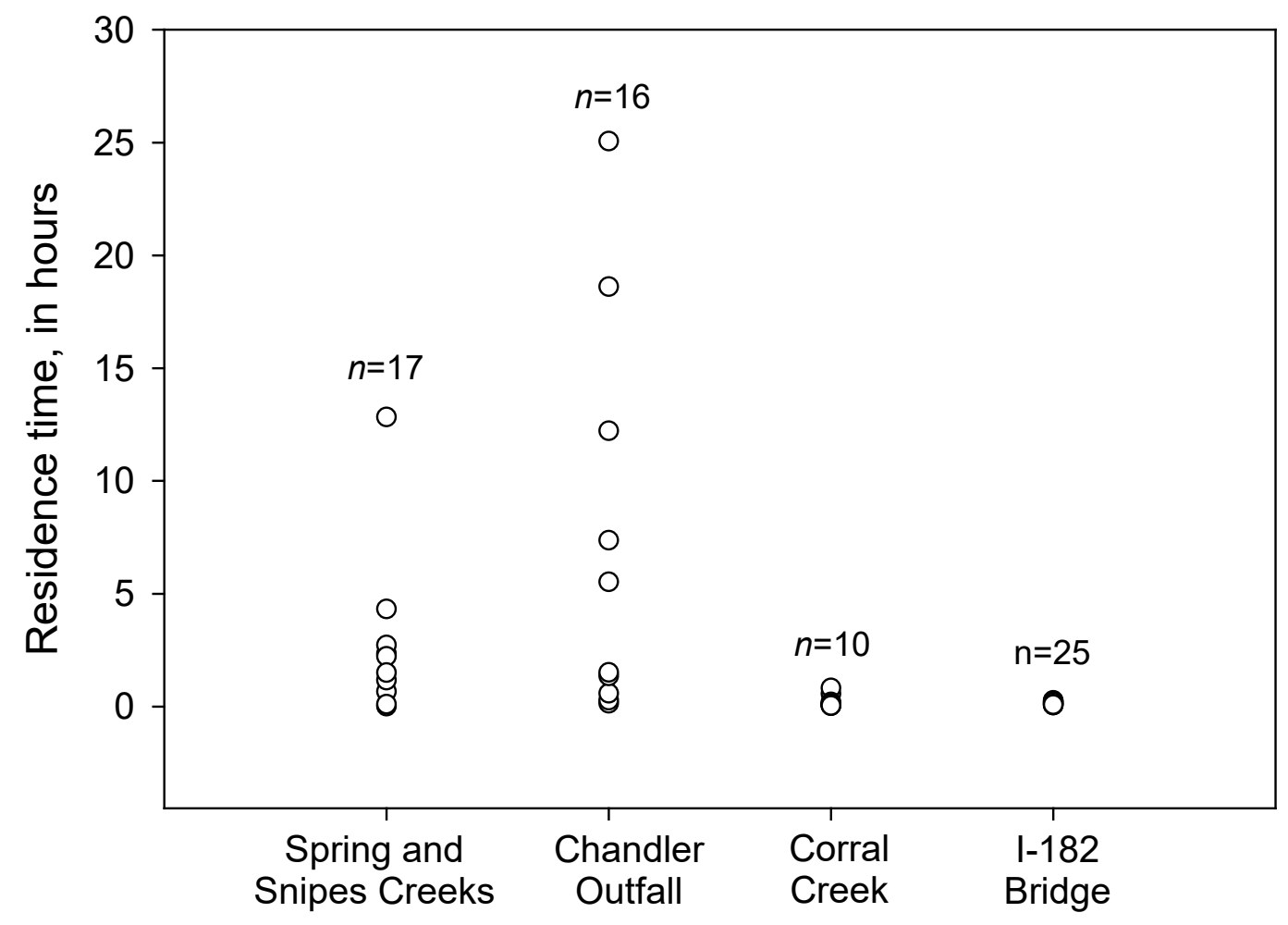

Figure 6. Graph showing residence time of radio-tagged adult sockeye salmon at potential cool-water refugia sites on the lower Yakima River, Washington. Multiple trips of fish are included, and total number of trips $(n)$ are shown above the data points for each site.

\section{Discussion}

This study empirically monitored a limited number of adult sockeye salmon in the lower Yakima River, which adds to a growing body of research on water temperature conditions and potential effects on migratory fish downstream from Prosser Dam during summer and early-fall months. Water temperature commonly exceeds $20^{\circ} \mathrm{C}$ in the lower Yakima River during summer and early fall (Appel and others, 2011), which is a critical threshold for Pacific salmon species (McCullough and others, 2001). Although these temperatures are likely to be uninhabitable for juvenile and adult life stages of Pacific salmon, there are distinct areas within the lower Yakima River where cool-water inputs exist (Appel and others 2011). Additional research is underway to provide new information on the temporal and spatial extent of these areas (Marcella Appel, Benton Conservation District, oral commun. 2019). Studies that describe fish behavior during summer and early-fall months provide important data for resource managers to determine the importance of these cool-water inputs. Part of the outmigration period for juvenile steelhead, coho salmon, and summer-run and fall-run Chinook salmon occurs in the lower Yakima River during May and June each year when water temperature is increasing. The upstream migration period for adult summer-run and fall-run Chinook salmon, and sockeye salmon occurs during July-October each year, which is when water temperature peaks, and then gradually decreases to $<20{ }^{\circ} \mathrm{C}$. Thus, these areas of cool-water inputs are potentially important for multiple species and life stages that use the lower Yakima River as a migration corridor. Our study was designed to determine how water temperature affected migration patterns of adult sockeye salmon in the lower Yakima River, and to determine if tagged fish used known areas of cool-water inputs. 
We determined that adult sockeye salmon collected and tagged at Prosser Dam and released into the lower Yakima River in late June moved downstream and out of the river shortly after release as water temperature increased in the system. Water temperature in the lower Yakima River ranged from 21 to $23{ }^{\circ} \mathrm{C}$ on tagging dates at Prosser Dam, and remained $>20{ }^{\circ} \mathrm{C}$ for nearly 3 months thereafter. None of the fish that left the Yakima River subsequently reentered the river, which indicates that they either selected another river for spawning or died. This result was troubling because these fish were collected while migrating upstream at Prosser Dam and were presumably of Yakima River-origin. Additionally, detections at monitoring sites located at known areas of cool-water refugia in the reach between Prosser Dam and the Yakima River mouth indicated that tagged fish moved quickly past these sites, rather than holding near them in late June and early July.

The effort to collect and tag fish at the Yakima River mouth allowed us to monitor the behavior of a limited number of tagged fish (eight fish) that eventually entered the river when water temperature cooled in September 2019. We determined that most of these fish (six out of eight fish) remained downstream from Prosser Dam, whereas two fish moved upstream and were detected at Roza Dam. Only one of these fish was eventually collected and transported upstream to Cle Elum Reservoir. Detections of tagged fish near known areas of cool-water refugia during fall months showed that fish spent more time (average $=3.6$ hours) at these locations in September and October than in late June and early July (average $=18.9$ minutes). Our study was designed to provide data on temperature use by tagged fish because many of the transmitters included temperature monitoring devices. However, we were unable to collect any of these devices because only one fish returned to Roza Dam and the locations of the remaining fish in the Yakima River were in areas where tag recovery was not possible. Additional research will be required to better understand temperature-use patterns by adult sockeye salmon in the lower Yakima River.

Fish that failed to enter the Yakima River after release at the Yakima River mouth eventually moved upstream or downstream in the Columbia River, or were never detected. This suggests that these fish selected another river for spawning, migrated in deep water where their radio transmitter was unlikely to be detected (Kuechle and Kuechle, 2012), or died. Post-season analysis of passive integrated transponder (PIT)-tag detections of adult summer Chinook salmon that were tagged in the Yakima River as juveniles showed that many fish were last detected in the upper Columbia River or Snake River (Mark Johnston, Yakama Nation Fisheries, oral commun., December 2019) during 2019. This suggests that elevated summer water temperature, which lasted for about 3 months in the lower Yakima River, prevented fish from entering the river during a critical migration period and eventually forced them to look elsewhere for spawning areas.

\section{Summary}

The behavior of a limited number of adult sockeye salmon (Oncorhynchus nerka) was observed in the lower Yakima River, Washington, during 2019 to assess fish responses to water temperature in the system. A group of fish were tagged and released in the river in late June and these fish moved downstream and left the river shortly after release when water temperatures were in the 21-23 degree Celsius $\left({ }^{\circ} \mathrm{C}\right)$ range. A second group of fish were tagged and released at the Yakima River mouth in late July and a subset of these fish eventually entered the river after water temperature decreased to $<20^{\circ} \mathrm{C}$ in September. Two of these fish eventually moved upstream to Roza Dam, but most fish remained in the river downstream from Prosser Dam. 
Tagged fish detected near known areas of cool-water refugia spent more time at these locations during fall months than in summer months. Additional research is recommended to assess these relations in subsequent years to better understand how these patterns vary on an annual basis.

\section{Acknowledgments}

Yakama Nation Fisheries provided labor, fish transport, and tagging support during the study. We also appreciate the efforts of Eric McCrea, Thor Ostrom, TJ Hester, Dan Charboneau, George Pressler, Paul Meyer, Mark Bove, Phil Moytka, Ryan Kilbury, John Merk, Joe Jancovic, Craig Nelson, Chris Tannahil, Ryan Ollero, Jeff Jones, Eric Jones, Teddy Schmitt, Ryan Thompson, and Cory Scott who served as volunteer anglers to collect adult sockeye salmon that were tagged and released at the mouth of the Yakima River. The Washington State Department of Ecology was a partner on this study, and we appreciate their involvement.

\section{References Cited}

Appel, M., Little, R., Wendt, H., and Nielson, M., 2011, Assessment of the lower Yakima River in Benton County, Washington: Report by the Benton County Conservation District to the Salmon Recovery Funding Board, 182 p., accessed October 2019, at http://www.ybfwrb.org/Assets/Documents/Assessments/Lower_Yakima_Assessment.pdf. Bureau of Reclamation, 2005, Phase I assessment report-Storage dam fish passage study, Yakima Project, Washington: Bureau of Reclamation Technical Series No. PN-YDFP-001, 75 p. plus appendixes. [Also available at

https://www.usbr.gov/pn/studies/fishpassage/phase1/entire-doc.pdf.]

Bureau of Reclamation, 2011, Cle Elum and Bumping Lake dams fish passage facilities planning report, storage dams fish passage study, Yakima project, Washington, 362 p., accessed October 2019. at http://dx.doi.org/10.3133/ofr20161003.

Donaldson, M.R., Cooke, S.J., Patterson, D.A., Hinch, S.G., Robichaud, D., Hanson, K.C., Olsson, I., Crossin, G.T., English, K.K., and Farrell, A.P., 2009, Limited behavioral thermoregulation by adult upriver-migrating sockeye salmon (Oncorhynchus nerka) in the Lower Fraser River, British Columbia: Canadian Journal of Zoology, v. 87, p. 480-490. [Also available at https://doi.org/10.1139/Z09-032.]

Ebersole, J.L., Liss, W.J., and Frissell, C.A., 2001, Relationship between stream temperature, thermal refugia and rainbow trout Oncorhynchus mykiss abundance in arid-land streams in the northwestern United States: Ecology of Freshwater Fish, v. 10, p. 1-10.

Ebersole, J.L., Liss, W.J., and Frissell, C.A., 2003, Thermal heterogeneity, stream channel morphology, and salmonid abundance in northeastern Oregon streams: Canadian Journal of Fisheries and Aquatic Sciences, v. 60, p. 1266-1280.

Eliason, E.J., Clark, T.D., Hague, M.J., Hanson, L.M., Gallagher, Z.S., Jeffries, K.M., Gale, M.K., Patterson, D.A., Hinch, S.G., and Farrell, A.P., 2011, Differences in thermal tolerance among sockeye salmon populations: Science, v. 332, p. 109112. [Also available at https://doi.org/10.1126/science.1199158.]

Hatch, D., Ward, A., Porter, A., and Schwartzberg, M., 1993, The feasibility of estimating sockeye salmon escapement at Zosel Dam using underwater video technology-1992 annual progress report: Prepared for Public Utility District No. 1 of Douglas County, Columbia River Inter-Tribal Fish Commission, Portland, Oregon, 27 p. 
Jeffries, K.M., Hinch, S.G., Sierocinski, T., Clark, T.D., Eliason, E.J., Donaldson, M.R., Li, S., Pavlidis, P., and Miller, K.M., 2012, Consequences of high temperatures and premature mortality on the transcriptome and blood physiology of wild adult sockeye salmon (Onchoryhchus nerka): Ecology and Evolution, v. 2, p. 1747-1764. [Also available at https://doi.org/10.1002/ece3.274.]

Keefer, M.L., Peery, C.A., and Heinrich, M.J., 2008, Temperature-mediated en route migration mortality and travel rates of endangered Snake River sockeye salmon: Ecology of Freshwater Fish, v. 17, p. 136-145. [Also available at https://doi.org/10.1111/j.1600-0633.2007.00267.x.]

Keefer, M.L., Peery, C.A., Ringe, R.R. ,and Bjornn, T.C., 2004, Regurgitation rates of intragastric radio transmitters by adult Chinook salmon and steelhead during upstream migration in the Columbia and Snake rivers: North American Journal of Fisheries Management, v. 24. P. 47-54.

Kuechle, V.B., and Kuechle, P.J., 2012, Radio telemetry in fresh water-The basics, in Adams, N.S., Beeman, J.S., and Eiler, J.H., eds., Telemetry techniques - A user guide for fisheries research: Bethesda, Maryland, American Fisheries Society, p. 91-138.

Macdonald, J.S., Foreman, M.G., Farrell, A.P., Williams, I.V., Grout, J., Cass, A., Woodey, J. C., Enzenhofer, H., Clarke, W.C., Houtman, R., Donaldson, E.M., and Barnes, D., 2000, The influence of extreme water temperatures on migrating Fraser River sockeye salmon (Oncorhynchus nerka) during the 1998 spawning season: Canadian Technical Reports of Fisheries and Aquatic Sciences, v. 2326, 117 p.

Major, R.L., and Mighell, J.L., 1967, Influence of Rocky Reach Dam and the temperature of the Okanogan River on the upstream migration of sockeye salmon: Fisheries Bulletin, v. 66, p. 131-147.

Martins, E.G., Hinch, S.G., Patterson, D.A., Hague, M.J., Cooke, S.J., Miller, K.M., Robichaud, D., English, K.K., and Farrell, A.P., 2012, High river temperature reduces survival of sockeye salmon (Oncorhynchus nerka) approaching spawning grounds and exacerbates mortality: Canadian Journal of Fisheries and Aquatic Sciences, v. 69, p. 330342. [Also available at https://doi.org/10.1139/F2011-154.]

Matala, A.P., Narum, S.R., Saluskin, B.P., Johnston, M.V., Newell, J.E., Fast, D.E., and Galbreath, P.F., 2019, Early observations from monitoring a reintroduction program-Return of sockeye salmon to a nursery lake of historical importance: Transactions of the American Fisheries Society, v. 148, p. 271-288. [Also available at https://afspubs.onlinelibrary.wiley.com/doi/pdf/10.1002/tafs.10133.]

Mathes, T.M., Hinch, S.G., Cooke, S.J., Crossin, G.T., Patterson, D.A., Lotto, A.G., and Farrell, A.P., 2010, Effect of water temperature, timing, physiological condition, and lake thermal refugia on migrating adult Weaver Creek sockeye salmon (Oncorhynchus nerka): Canadian Journal of Fisheries and Aquatic Sciences, v. 67, p. 70-84. [Also available at https://doi.org/10.1139/F09-158.]

McCullough, D., Spalding, S., Sturdevant, D., and Hicks, M. 2001, Summary of technical literature examining the physiological effects of temperature on salmonids: U.S. Environmental Protection Agency Issue Paper 5, Document EPA-910-D-01-005, 118 p. [Also available at https://www.critfc.org/blog/reports/summary-of-technical-literature-examiningthe-physiological-effects-of-temperature-on-salmonids/.] 
Quinn, T.P., Hodgson, S., and Peven, C., 1997, Temperature, flow, and the migration of adult sockeye salmon (Oncorhynchus nerka) in the Columbia River: Canadian Journal of Fisheries and Aquatic Sciences, v. 54, p. 1349-1360. [Also available at https://doi.org/10.1139/cjfas-546-1349.]

Rand, P.S., Hinch, S.G., Morrison, J., Foreman, M.G.G., MacNutt, M.J., Macdonald, J.S., Healey, M.C., Farrell, A.P., and Higgs, D.A., 2006, Effects of river discharge, temperature, and future climates on energetics and mortality of adult migrating Fraser River sockeye salmon: Transactions of the American Fisheries Society, v. 135, p. 655-657. [Also available at https://doi.org/10.1577/T05-023.1.]

U.S. Environmental Protection Agency, 2012, Primer for identifying cold-water refuges to protect and restore thermal diversity in riverine landscapes: U.S. Environmental Protection Agency Report Number 910-C-12-001, 91 p. [Also available online at https://nepis.epa.gov/Exe/ZyPDF.cgi/P100E45N.PDF?Dockey=P100E45N.PDF.]

Yakama Nation, 1990, Columbia Basin system planning salmon and steelhead production plan, Yakima River subbasin: Confederated Tribes and Bands of the Yakima Indian Nation, 237 p., accessed October 2019, at

http://docs.streamnetlibrary.org/Subbasin_Plans/Columbia_Plateau_North/Yakima90.pdf. 

Publishing support provided by the U.S. Geological Survey Science Publishing Network, Tacoma Publishing Service Center

For more information concerning the research in this report, contact the Director, Western Fisheries Research Center

U.S. Geological Survey 6505 NE 65th Street

Seattle, Washington 98115-5016

https://www.usgs.gov/centers/wfrc 


\section{㞭}

중

言

兵

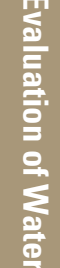

兽

謇

항

을

通

遂

을

홀.

产

꿍

赵

兽

के

훙

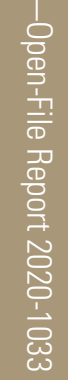

ISSN 2331-1258 (online)

https://doi.org/10.3133/ofr20201033 